\title{
分岐補題の抽出による極小モデル生成の効率化 Improving the Efficiency of Minimal Model Generation by Extracting Branching Lemmas
}

\author{
$\begin{array}{ll}\text { 長谷川 隆三 } & \begin{array}{l}\text { 九州大学 大学院システム情報科学研究院 } \\ \text { Ryuzo Hasegawa } \\ \text { hasegawa@ear.is.kyushu-u.ac.jp }\end{array}\end{array}$ \\ $\begin{array}{ll}\text { 藤田 博 } & \text { (同 } \stackrel{\text { 上) }}{\text { Hiroshi Fujita }} \quad \text { fujita@ar.is.kyushu-u.ac.jp }\end{array}$ \\ 越村 三幸向上) \\ Miyuki Koshimura koshi@ar.is.kyushu-u.ac.jp
}

keywords: model generation, minimal models, automated reasoning, theorem proving, SATCHMO, MGTP

\section{Summary}

We present an efficient method for minimal model generation. The method employs branching assumptions and lemmas so as to prune branches that lead to nonminimal models, and to reduce minimality tests on obtained models. Branching lemmas are extracted from a subproof of a disjunct, and work as factorization. This method is applicable to other approaches such as Bry's constrained search or Niemelä's groundedness test, and greatly improves their efficiency. We implemented MM-MGTP based on the method. Experimental results with MM-MGTP show a remarkable speedup compared to MM-SATCHMO.

\section{1.まえがき}

極小モデルの概念は , 論理プログラミング , 演繹デー タベース, ソフトウェア検証, 仮説推論等の幅広い分野 で重要である．また実際上も，応用によっては，一階述 語論理の節集合に対して極小なエルブランモデルを生成 することが必要となる。

従来のタブロー法や Davis-Putnam 法はすべての極小 モデルを生成できるが, 不要な非極小モデルも生成して しまうため効率が悪い．一般に，モデル $M$ が極小であ ることを保証するには， $M$ が他のモデルに包摂されない ことを確かめる必要がある . これを $M$ の極小性検査と 呼ぶ．しかし，モデル数の増加に伴い極小性検査のコス 卜が増大するので , 非極小モデルの生成自体を避けるこ とが重要である .

最近，タブローの枠組で2つの典型的な方法か報告され た . Bry と Yahya[Bry 96] は，極小モデルを生成する健 全かつ完全な手続きを与え，Prolog でMM-SATCHMO を実装した .この手続きは，相補分割 (complement splitting) と制約下探索 (constrained search) を用いて，モデ ル構築時に非極小モデルを㕕却する . 一方，Niemelä は， 制約下探索の代りに，根拠検査 (groundedness test) を導 入した命題タブロー計算法を提示した [Niemelä 96] . し かし，両方法とも次のような欠点をもつ.すなわち，証明
木を解析すれば簡単に極小性が確認できるようなモデル に対して，不要な極小性検査を行なってしまうこと，お よび，非極小モデルを導くような冗長な探索枝を完全に は刚りきれないことである .

これらの問題を解決するため, 本論文では相補分割を 強化した分岐補題 (branching lemma) と呼う溉念を導入 する . 分岐補題の適用により，非極小モデルに至るモデ ル候補が早期に萧却されて探索空間が大きく削減された り，場合によっては生成されたモデルの極小性が保証さ れるため，極小性検査を省略できるなどの効率化が得ら れる .この手法は, 因子化 (factorization) [Letz 94] の一 実現方式とみることができる. 因子化は, 元来, 充足不 能な節集合に対する反駁証明における探索木の枝刈り手 法で, 証明委託という概念に基づくものであるが , ここ では，この考え方を逆に充足可能な節集合に対する極小 モデル生成という観点から捉えなおしている点が新しい . 分岐補題の手法はタブロー法に基づく定理証明において 汎用的であり，実際に上記の二つの方法に適用して無の 能力を補強することも可能である.

我々は，この方法を CMGTP[白井 97] の機能を備え た Java 版 MGTP [藤田 98, 長谷川 99, 長谷川 00] 上に 実装した .これを MM-MGTP と呼ぶ. MM-MGTP は， MM-SATCHMO と同樣に,一階述語論理の節集合に適 用可能である.実験の結果，MM-SATCHMO に比べ顕 


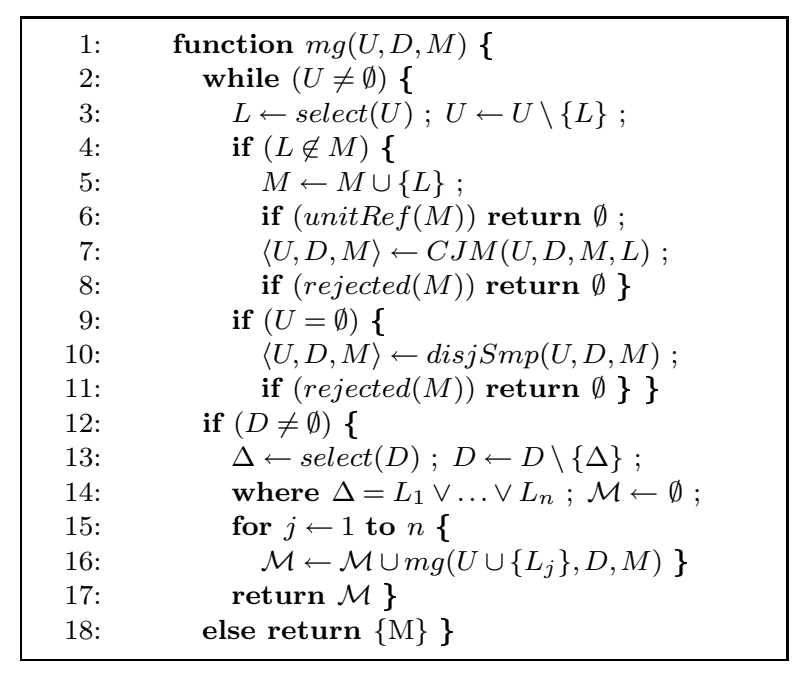

図 1 MGTP の証明手続き

著な速度向上が確認された 。

本論文の構成は以下のとおりである .2 章で MGTP の基本的証明手続きを示し， 3 章では極小モデル生成の ための相補分割および分岐補題について述べた後，これ らの機能をMGTP に導入して拡張した MM-MGTP の 証明手続きを示す .さらに，4 章で MM-MGTP の健全 性と完全性を証明し， 5 章では MM-MGTP の実装につ いて簡単に触れた後, 主に MM-SATCHMO との比較評 価実験の結果を示す . 6 章て関連研究について議論し, 7 章で結論を述べる．

\section{MGTP}

任意の一階述語論理式は, 含意式表現による節 (clause) $A_{1} \wedge \ldots \wedge A_{m} \rightarrow B_{1} \vee \ldots \vee B_{n}$ の集合*1で与えられる. ここで, $A_{i(1 \leq i \leq m)}$ と $B_{j(1 \leq j \leq n)}$ はリテラルである.$\rightarrow$ の左辺を前件，右辺を後件という. 前件が true $(m=0)$ の節を正節，後件が false $(n=0)$ の節を負節という.正節 (負節) でない節を非正節 (非負節) という．また， $n \leq 1$ の節をホーン節， $n>1$ の節を非ホーン節という.さら に，後件中の变数がすべて前件にも出現するとき，值域 限定 (range-restricted) 節という . また , 基礎 (ground) リテラル集合 $M$ に対し，ある代入 $\sigma$ のもとで $(\forall i(1 \leq$ $\left.i \leq m) . A_{i} \sigma \in M\right) \wedge\left(\forall j(1 \leq j \leq n) . B_{j} \sigma \notin M\right)$ が成立 するとき， $M$ における違反 (violated) 節という .

MGTP の証明手続きは，值域限定された節集合 $S$ に 対して, 最初に空のモデル候補 $M$ を設定し, $S$ 中に違反 節が見出されなくなるまで $M$ を段階的に拡張する (モ デル候補拡張）操作を繰り返すことにより，エルブラン モデルを具体的に生成する.MGTP では,節集合に関数 記号の出現が許されるので, 一般には無限要素のエルブ ランモデルの生成過程に陥り停止しなくなる可能性があ

$* 1$ 本論文では, 節中のリテラル, および, 節集合中の節は順序 付きであり，記述された順序に従うものとする．
$\frac{L \in M \quad \neg L \in M}{\perp}$

図 2 単位反駁規則
$\frac{L \in M \quad \neg L \vee \mathcal{C} \in D}{\mathcal{C}}$

図 3 選言簡約規則
るが, 要素数が有限のエルブランモデルが存在するとき には光れを出力することができる．また，エルブランモ デルが存在しない (充足不能な) 節集合に対しては，モ デル生成の有限失敗 (可能なあらゆるモデル候補の棄却) によってこれを決定できる .

MGTP の証明手続きの概要を図 1 に示す. 関数 $m g$ は, 入力として基礎リテラル集合 $U$ と基礎選言集合 $D$, およ びモデル候補 $M$ を受け取り，モデルの集合を出力する . 与えられた值域限定節集合 $S$ のうちすべてのホーン正節 の集合 $U_{0}$ を $U$ ，すべての非ホーン正節の集合 $D_{0}$ を $D$ に置き， $M=\emptyset$ として $m g$ のトップレベル呼出しを起動 すると， $S$ のエルブランモデル集合が返される.$S$ のう ちすべての非正節は関数 $C J M$ から暗黙に参照される. $m g$ の動作は次のとおりである .

ホーン拡張フェーズ (2〜11 行目) Uが空でなければ select 関数でリテラル $L$ を一つ取り出す. $L$ が $M$ に包摂されない $(L \notin M)$ 場合，モデル候補 $M$ を $L$ で拡張したものを新たな $M$ とする (ホーン拡張) . この新たな $M$ に対して図 2 の単位反駁が成立して 関数 unitRef が真值を返す場合には $M$ を棄却し， ただちに $m g$ はりを返して終わる (6 行目) .さも なければ, 連言照合関数 $C J M$ を呼び, 前件が $M$ で充足される節 ${ }^{2}$ を探す . 見つかった節が負節の場 合， $C J M$ は $M$ に棄却の印を付け, $m g$ はこの印が あれば (rejected) 空集合を返して終わる (8行目) . 見つかった節が非負節の場合, 弚れがホーン節か非 ホーン節かに応じて产の後件を $U$ または $D$ に付加 して更新する .

9 行目でUが空のとき, 関数 $d i s j S m p$ を呼び, 図 3 に示す選言簡約および $M$ に対する $D$ の包摂検査 を行なう，選言簡約の結果，単位節が導かれた場合， その単位節を $D$ から $U$ へ移す.空節が導かれた場 合は, disjSmp は $M$ に棄却の印を付け，これを検 知した $m g$ は空集合を返して終わる.

非ホーン拡張フェーズ (12〜17 行目) $D$ カか空でなけれ ば select 関数で選言 $\Delta$ を一つ取り出す. $\Delta$ の各選 言要素 $L_{j}(1 \leq j \leq n)$ を $U$ に加えて再帰的に $m g$ を呼び， $M$ の分岐拡張を行なう (非ホーン拡張). これら $m g$ の各再帰呼出しが返すモデル集合の合併 を当 $m g$ の值として返す．

モデル出力 $(18$ 行目 $) U$ と $D$ の両方とも空のとき,$M$ のみを要素とする集合を返す．

$* 2$ 前件が $M \backslash\{L\}$ で充足されるものは, $L$ による拡張前の $M$ における連言照合計算と重複するので省く . また， $M$ のもと での違反節を定めるための後件に対する検査は, 图 1 の 4 行 めと 10 行めの包捸検査に含まれるので省く. 


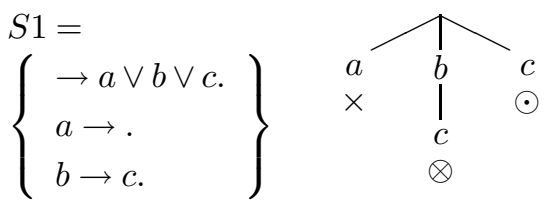

図 4 節集合 $S 1$ と炎の証明木

MGTP の証明手続きの実行にともなって，空要素を根 とし，図 1 の 5 行目でのホーン拡張における $L$, および， 16 行目の非ホーン拡張における $L_{j}$ を節点とするような 木を構成することができる .この木を MGTP の証明木 と呼:゙*3. 根からある節点に至る一本の枝 (経路) 上の すべてのリテラルからなる集合が一つのモデル候補に対 応する.

例として，図 4 に節集合 $S 1$ と炎れに対する MGTP の証明木を示す . 図 4 の $\{a\}$ のように萧却されたモデル 候補に対応する枝を失敗枝と呼び，光の葉に $\times$ の印を付 す．一方，モデルに対応する枝を成功枝と呼ぶ．

さて , 二つのモデル $M$ と $M^{\prime}$ との間に集合としての 包含関係 $M \supseteq M^{\prime}$ が成立するとき， $M$ は $M^{\prime}$ に包捸さ れるという．また，モデル集合 $\mathcal{M}$ 中の要素 $M$ に対し， $\forall M^{\prime} \in \mathcal{M} . M \supseteq M^{\prime} \rightarrow M=M^{\prime}$ が成立するとき， $M$ は $\mathcal{M}$ において極小であるという . $m g$ の出力するモデル集 合 $\mathcal{M}$ については，極小でないモデルが含まれるかもし れない．また，(集合として) 同一の極小モデルが証明木 の異なる枝として複数回生成されるかもしれない(たと えば図 6 の節集合 $S 2^{\prime}$ ) .

図 4 では二つのモデル $M_{1}=\{b, c\}$ と $M_{2}=\{c\}$ が得 られるが， $M_{1}$ は $M_{2}$ によって包摂され極小でない．成 功枝の葉に付けられた $\odot(\otimes)$ の印は，弚の枝に対応する モデルが極小 (非極小) であることを示す．

\section{MM-MGTP}

\section{$3 \cdot 1$ 極小モデル生成}

選言 $a \vee b \vee c$ は $(a \wedge \neg b \wedge \neg c) \vee(b \wedge \neg c) \vee c$ と等価で ある.したがって，図 4 の節点 $b$ の下に $\neg c$ を付加して よい.ここで付加した選言要素 $c$ の相補リテラル $\neg c$ を 分岐仮定 (branching assumption) と呼び， $[\neg c]$ と表す. こうすると, 節点 $b$ に付加された分岐仮定 $[\neg c]$ と $b$ から 導かれる $c$ とに単位反駁規則を適用して $\{b, c\}$ を充却で きる．乥こで，一般に， $L_{1} \vee L_{2} \vee \ldots \vee L_{n}$ の非ホーン節 によるモデル候補拡張を， $\left(L_{1} \wedge\left[\neg L_{2}\right] \wedge \ldots \wedge\left[\neg L_{n}\right]\right) \vee$ $\left(L_{2} \wedge\left[\neg L_{3}\right] \wedge \ldots \wedge\left[\neg L_{n}\right]\right) \vee \ldots \vee L_{n}$ に修正する .これ は, まさに相補分割規則 [Bry 96] の適用に相当する .

Bry と Yahya[Bry 96] が証明したように，相補分割は 証明木の最左モデルが常に極小であることを保証する． しかし, 証明木の他の枝において得られるモデルは必ず

\footnotetext{
$* 3$ 証明木の節点は, 紛れがない限り，これをラベル付けるリテ ラルで直接指し示すことにする．
}

$$
S 2=\left\{\begin{array}{c}
\rightarrow a \vee b . \\
b \rightarrow a .
\end{array}\right\} \quad S 2^{\prime}=\left\{\begin{array}{l}
\rightarrow a \vee b . \\
b \rightarrow a . \\
a \rightarrow b .
\end{array}\right\}
$$

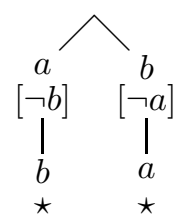

図 5 右枝の非極小モデル

図 6 不健全な分岐仮定

しも極小ではない .たとえば，図 5 の節集合 $S 2$ に対し ては最左枝に極小モデル $\{a\}$ を得るが, 弚の右の枝では 非極小モデル $\{b, a\}$ が得られる .

生成されるあらゆるモデルが極小であることを保証す るために, MM-SATCHMO は, モデル制約 (model constraints)[Bry 96] を用いた制約下探索に基づき，以下の ように実行する . 極小モデル $\left\{L_{1}, \ldots, L_{m}\right\}$ が得られたと き，モデル制約，すなわち，負節 $L_{1} \wedge \ldots \wedge L_{m} \rightarrow$ を新 たに生成して節集合に加える．たとえば，図 5 において， 極小モデル $\{a\}$ が得られたとき，負節 $a \rightarrow$ が $S 2$ に加え られ，これによって非極小モデル $\{b, a\}$ が充却される．

しかし, 上の方法では新たな極小モデルが確定する度 に負節を動的に加えていかねばならず, 兴の数は指数的 に増大しうる.特に，MM-SATCHMO においてはモデ ル候補拡張の度に光れらの負節に対する連言照合が実行 されるため, 多大なオーバヘッドが生じる .この問題を 避けるためには, Niemelä の方法 [Niemelä 96] が有効 と考えられる . この方法は以下のようなものである . モ デル $M=\left\{L_{1}, \ldots, L_{m}\right\}$ が得られたとき， $S$ を入力節集 合 , $\bar{M}=\left\{\neg L^{\prime} \mid L^{\prime} \notin M\right\}$ として,$\forall L \in M . S \cup \bar{M} \models L$ が成り立つか否かを検査する . 成立すれば $M$ は極小と 判定される.この検査は根拠 (groundedness) 検査と呼 ばれるが，一時的に節を増強した節集合 $S_{M}=S \cup \bar{M} \cup$ $\left\{L_{1} \wedge \ldots \wedge L_{m} \rightarrow\right\}$ に対して，タブロー計算を新たにや り直すことに他ならない． $S_{M}$ が充足不能であれば， $M$ は極小であり，さもなければ非極小であるといえる．

\section{$3 \cdot 2$ 分 岐 補 題}

$S 2$ の第 1 節を $\rightarrow b \vee a$ で置き換えれば，非極小モデ ル $\{b, a\}$ は左枝に現れて分岐仮定 $[\neg a]$ にり菓却され， 右枝に極小モデル $\{a\}$ が得られる . したがって , 図 5 に おいても $[\neg a]$ を右節点 $b$ に加えて右枝の非極小モデル $\{b, a\}$ を㶳却しても問題ないと考えられる.

ところが, 一般に左の選言要素に右の選言要素からの 分岐仮定を付加した上, 右の選言要素に対して左の選言 要素からの分岐仮定を付加すると，両立的選言を排他的 選言として扱うことになり，不健全な推論となる。

たとえば，図 6 の節集合 $S 2^{\prime}$ を考える . 証明木の葉に 付されたネは，分岐仮定によってモデル候補が菓却され 


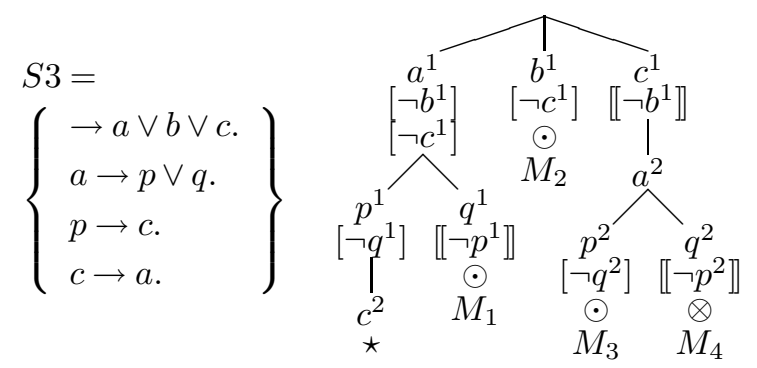

図 7 分岐補題を用いた証明木

たことを示す . 左側では $\{a, b\}$ を $[\neg b]$ によって，右側で は $\{b, a\}$ を $[\neg a]$ によって棄却したため, $S 2^{\prime}$ の極小モデ ル $\{b, a\}(=\{a, b\})$ を得るのに失敗している.

乥こで, 非ホーン拡張時における分岐仮定の健全な適 用について論じるために，以下のような定義を行なう．

【定義 3·1】 $L_{i}$ を非ホーン拡張で用いられた選言 $L_{1} \vee$ $\ldots \vee L_{n}$ の要素とする . $L_{i}$ 以下の枝が，ある弟選言要素 $L_{j}(i+1 \leq j \leq n)$ による分岐仮定 $\left[\neg L_{j}\right]$ によって閉じ られるとき, $L_{i}$ を $L_{j}$ への委託選言要素という.また , こ のとき弟選言要素 $L_{k}(i+1 \leq k \leq n)$ はすべて,$L_{i}$ から の被委託選言要素という.

【定義 3·2】 非ホーン拡張で用いられた $L_{1} \vee \ldots \vee L_{n}$ 中の $L_{i}$ が委託選言要素でないとき, $\neg L_{i}$ を弟選言要素 $L_{j}(i+1 \leq j \leq n)$ のすべてに付加する .この $\neg L_{i}$ を分 岐補題といい, $\llbracket \neg L_{i} \rrbracket$ と表す.

たとえば，図 7 において，分岐仮定 $\left[\neg c^{1}\right]$ が $a^{1}$ の下の 枝を閉じるのに使用されているので, $a^{1}$ は委託選言要素 である .ここで, リテラルの肩に付された添字は, 同一 リテラルの異なる出現を区別するためのものである . ま た, 節点 $c^{2}$ にかが付されているのは, この節点以下の証 明が別の節点 $\left(c^{1}\right)$ の証明に委託されていることを示し ている.$a^{1}$ の弟選言要素 $b^{1}, c^{1}$ は $a^{1}$ からの被委託選言 要素である . 分岐補題 $\llbracket \neg p^{1} \rrbracket, \llbracket \neg b^{1} \rrbracket, \llbracket \neg p^{2} \rrbracket$ は, 委託選言 要素でない $p^{1}, b^{1}, p^{2}$ から光れ光れ生成されるが, $\llbracket \neg a^{1} \rrbracket$ という分岐補題は, $a^{1}$ か涹託選言要素であるため生成さ れない .

【定義 3·3】 $M$ をある証明木で得られたモデルとする $M$ が非ホーン拡張で用いられた $L_{1} \vee \ldots \vee L_{n}$ 中の被委 託選言要素 $L_{j}$ を含むとき, $L_{j}$ へ 委託した選言要素 $L_{i}$ $(1 \leq i \leq j-1)$ を,$M$ に関する委託選言要素という. $M$ が被委託選言要素を含まないとき， $M$ は安全であるとい い,さもなければ， $M$ は要注意であるという .

$\S 1$ 分岐補題による枝刈り

分岐補題の第一の効果として, 图 8 に示すように, 分 岐仮定では刈れない非極小モデルの枝を刈ることができ る.まず.最左枝の節点 $a$ は委託選言要素でないので, 分

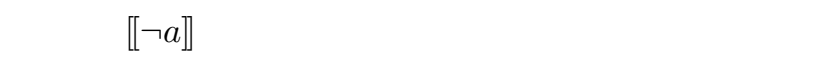
る.葉に付されたネが分岐補題による枝刈りを示してい る. 同じく, 節点 $b$ は委託選言要素でないので, 分岐補

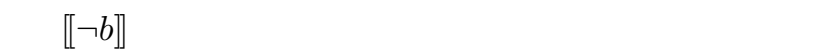

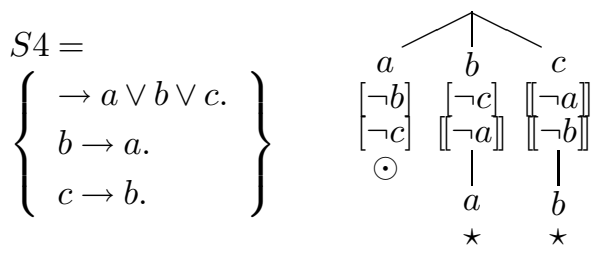

図 8 分岐補題による枝刈り

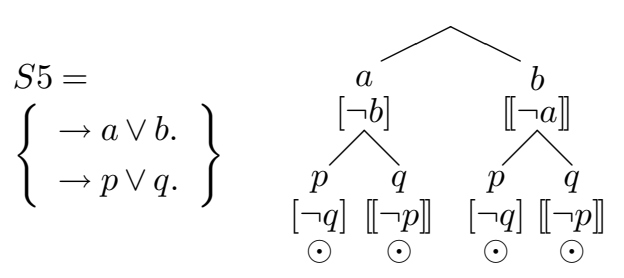

図 9 極小性検査の省略

こで, 失敗枝であっても分岐仮定を使用していない限り 分岐補題を生成できることに注意 .

分岐補題の適用を因子化の観点から言い換えると, 図

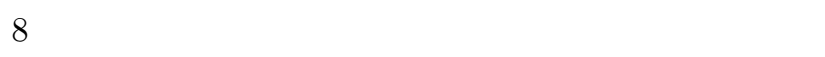
れ証明を委託するということである．本来，因子化にお いては委託の循環が生じないかぎり，委託の方向（証明 木における分枝の左右) の制限はない.これに対し, 分 岐仮定では常に左から右への委託のみか許されているの で，これを $S 4$ に適用しても上記のような枝刈りが行な えない．しかし，たとえば $S 4$ の第1節のリテラル順序 を逆順にして $\rightarrow c \vee b \vee a$ とすれば, 分岐仮定のみで2 本の枝を刈ることができる. 分岐補題は, 分岐仮定の効 果に関するリテラル順序への依存性を緩和して, 因子化 の機能を回復するものである .

\section{$\S 2$ 極小性検査の省略}

第二に, 分岐補題は極小性検査の回数を大幅に削減する 効果を有する.今 , 得られたモデル $M$ が安全であるとし よう. 定義 $3 \cdot 3$ により $M$ は被委託選言要素を一つも含ま ないが, これは $M$ 中のすべての選言要素のすべての兄選 言要素から分岐補題が得られるということと等価である . このとき， $M$ は極小であることが保証され，極小性検査を 省くことができる.これは, 直観的には次のように正当化 される．もし， $L_{j} \in M$ がある選言 $L_{1} \vee \ldots \vee L_{n}$ の要素 であるとき, $M$ は安全なので, 定義 $3 \cdot 3$ により, $L_{j}$ は被 委託選言要素ではない . 兄の選言要素 $L_{k}(1 \leq k \leq j-1)$ の各々について，もし $L_{k}$ を含むようなモデル $M^{\prime}$ があれ ば，次のことを満たす．分岐仮定 $\left[\neg L_{j}\right]$ のもとに $L_{j} \notin M^{\prime}$

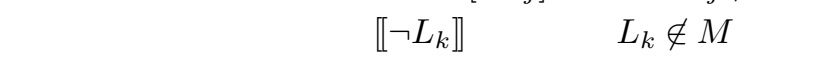
る.したがって， $M$ は $M^{\prime}$ に包摂されない .

たとえば, 図 9 において S5 のモデルはすべて安全で あり，極小性検査を行なうまでもなく極小であることが 保証される . 


\section{$\S 3$ 極小性検査の範囲限定}

一方，得られたモデル $M$ が要注意であるとき， $M$ と 兴れ以前に得られたモデルとの間で極小性検査が必要と なる．しかし，極小性検査は $M$ に関する委託選言要素 を含むモデルとの間だけ行なえばよい．これを，限定し た極小性検査という，極小性検査が必要となる理由は以 下のとおりである.$L_{k}$ を $M$ に関する委託選言要素, $L_{j}$ を $L_{k}$ から委託された $M$ 中の被委託選言要素, $M^{\prime}$ を $L_{k}$ を含むモデル，としよう．分岐仮定 $\left[\neg L_{j}\right]$ のもとでは， $L_{j} \notin M^{\prime}$ であるが， $M$ に対して分岐補題 $\llbracket \neg L_{k} \rrbracket$ は許さ れていないので, $L_{k} \in M$ かもしれない.すなわち， $M$ は $M^{\prime}$ に包摂される可能性がある .

たとえば，図 7 において，モデル $M_{1}$ は被委託選言要 素を含まないので安全である。したがって， $M_{1}$ に対する 極小性検査は省いてよい，モデル $M_{2}, M_{3}, M_{4}$ は，被委 託選言要素 $b^{1}$ あるいは $c^{1}$ を含むので要注意である．し たがって，極小性検査が必要となる.$a^{1}$ はこれらの各モ デルに関する唯一の委託選言要素であるから，これらの モデルに対する極小性検査は， $a^{1}$ を含む $M_{1}$ に対しての み行なわれる ${ }^{4}$. 実際, この検査の結果， $M_{4}$ は $M_{1}$ に 包摂されて非極小であることがわかる.

\section{3·3 MM-MGTP 証明手続き}

本節では, 極小モデル生成のための MGTP の改良版 として，Bry と Yahya の方法に基づくモデル記憶型，お よび Niemelä の方法に基づくモデル再計算型の 2 種類の MM-MGTP の証明手続きを示す .

\section{$\S 1$ モデル記憶型 MM-MGTP}

図 10 にモデル記憶型 MM-MGTP の証明手続きを示 す.内側の枠で囲った部分は, 図 1 に対する追加/修正箇 所である．モデル記憶のために証明木 ${ }^{* 5}$ を実際に構築す る必要があるので, 図 10 では証明木の内部表現を $\mathrm{mmg}$ の引数 $T$ に保持し $\left(1^{\prime}, 16^{\prime}\right.$ 行目) , 常に現在拡張中の枝 の先端節点 (以下, 拡張端と呼ぶ) が参照できるものと する .

分岐仮定の適用 $(\mathrm{i}, \mathrm{ii}$ 行目) 分岐仮定 $[\neg L]$ か設定され ていれば (assumed)，モデル候補 $M$ を棄却し，こ の適用を記録する (mark_used) .

分岐補題の適用 (iii 行目) 分岐補題 $\llbracket L \rrbracket$ が設定されて

いれば (asserted)，モデル候補 $M$ を棄却する .

証明木拡張 (iv 行目) 証明木 $T$ の拡張端に枝を延ばし

て節点 $L$ を加え，これを新たな拡張端とする . 分岐仮定設定 $(v, v i$ 行目)

分岐仮定 $\left[\neg L_{2}\right],\left[\neg L_{3}\right], \ldots,\left[\neg L_{n}\right]$ を設定する (assume) . 15 行目以降で $L_{j}(j>1)$ の分岐が行われる毎に $\left[\neg L_{j}\right]$ を解除する (reset_assumption) .

$* 4$ さらに限定して,$M$ が要注意モデルであっても， $M$ に関す る委託選言要素を含まなければ， $M$ に対する極小性検査は省 くことができる. $M_{2}$ が光の例である

*5 実際には棄却されたモデル候補に至る不要な枝は省き，極小 モデルの枝のみを残した木を保持すればよい .

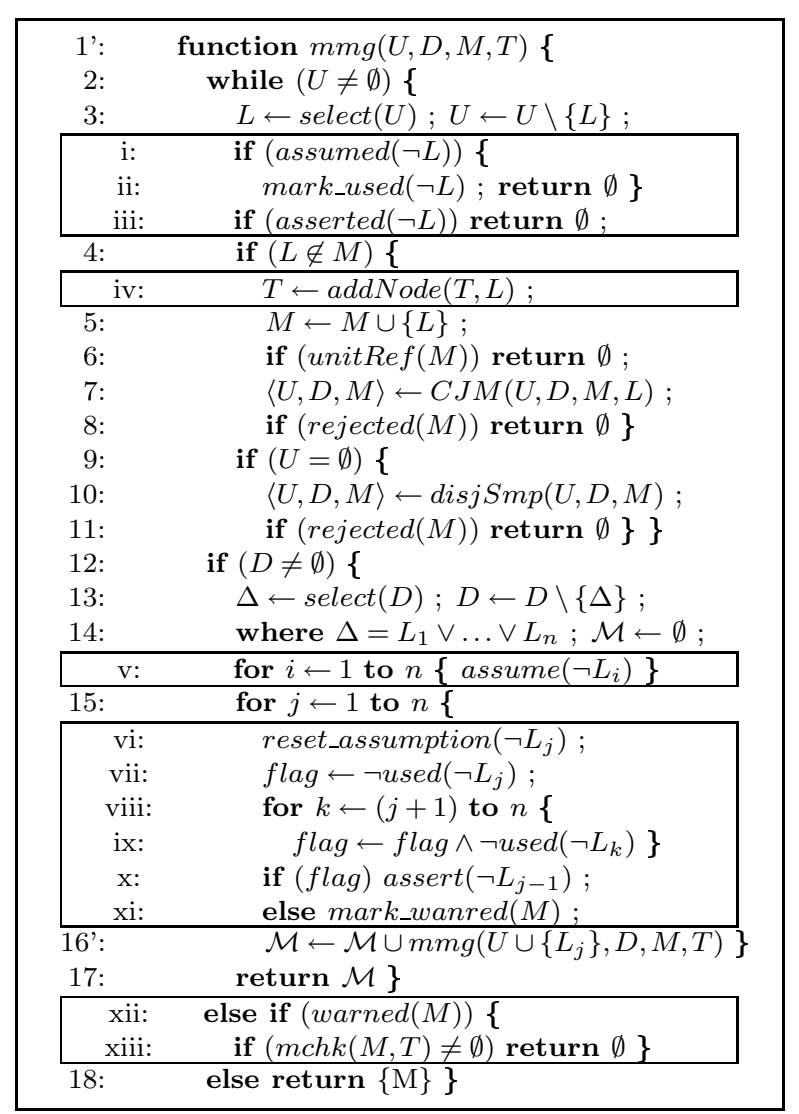

図 10 モデル記憶型 MM-MGTP の証明手続き

分岐補題設定 (vii xi 行目) 直前の選言要素 $L_{j-1}$ に 対する $m m g$ の実行で分岐仮定 $\left[\neg L_{j}\right],\left[\neg L_{j+1}\right], \ldots$, $\left[\neg L_{n}\right]$ のいずれも使用されていなければ ( $\neg$ used)， 【 $\neg L_{j-1} \rrbracket$ を設定する (assert) . 分岐補題か設定でき なかった場合は, 現モデル候補 $M$ に要注意と印す (mark_warned) .

極小性検査 $(x i i$, xiii 行目) この時点で, $M$ に要注意 と印されていれば (warned), 関数 $\operatorname{mch} k(M, T)$ に より証明木 $T$ を踏査して，これまでに確定したモデ ルの中から $M$ を包摂する $M^{\prime}$ を探す.$M^{\prime}$ が見つか れば $M$ は非極小であり， $m m g$ は空集合を返す．さ もなければ極小モデル $M$ が確定する .

ここで， $M$ に真に包含されるモデル $M^{\prime}$ がある場合は， 必ず証明木において $M$ 上り左にあって右にはないこと， および， $M$ に等しいモデルが $M$ の左右では決して得ら れないことにも注意 .これらは分岐補題には拠らず，相 補分割に従っていることのみからの帰結である .

\section{$\S 2$ モデル再計算型 MM-MGTP}

モデル再計算型 MM-MGTP の証明手続きは, 図 10 の $m m g$ に対し，以下の変更を施して得られる.

•証明木の構築が不要なので, $1^{\prime}, 16^{\prime}$ 行目の $m m g$ の 引数 $T$, および iv 行目を削除

-xiii 行目の $m c h k(M, T)$ をモデル再計算関数 $\operatorname{rcmp}\left(M, U_{0}, D_{0}, \emptyset\right)$ で置き換える .ここで, $M$ は 検査対象のモデル, $U_{0}, D_{0}$ は $m g や m m g$ のトップ 
レベル呼出しで用いられた $U, D$ の初期值, $\emptyset$ は再計

算されるモデル候補の初期值とする .

$r c m p$ の本体自体も図 10 の $\mathrm{mmg}$ と同樣であるが， 以下の変更を施して得られる .ここで, 検査対象のモ デルを再計算されるモデル $M$ と区別するため, $M^{o}=$ $\left\{L_{1}^{o}, \ldots, L_{m}^{o}\right\}$ と表す.

-1' 行目の $m m g(U, D, M, T)$ を $r c m p\left(M^{o}, U, D, M\right)$ で, 16 ' 行目の $m m g\left(U \cup\left\{L_{j}\right\}, D, M, T\right)$ を $r c m p($ $\left.M^{o}, U \cup\left\{L_{j}\right\}, D, M\right)$ で置き換える .

・vi, xii, xiii 行目を削除.

- 関数 $C J M$ カ暗黙に参照する入力節集合に，一時的 に負節 $C_{M^{o}}=L_{1}^{o} \wedge \ldots \wedge L_{m}^{o} \rightarrow$ を加える .

• $L \notin M^{o}$ なるリテラル $L$ によるモデル候補拡張にお いては, 前提となっている $\overline{M^{\circ}}$ により単位反駁が成 立するとみなされるので, ただちに兴のモデル候補 を棄却する．このため， 3 行目の直後に，

$3.5: \quad$ if $\left(L \notin M^{o}\right)$ return $\emptyset$;

\section{を挿入する .}

・ r cmp は $M^{o}$ を包摂するモデルを一つでも生成すれ ば終了してよいので, 16'行目の\}を削除し，

$16.5: \quad$ if $(\mathcal{M} \neq \emptyset)$ return $\mathcal{M}\}$

を挿入する .

$r c m p$ か空集合を返せば $M^{o}$ か極小であると言える.さ もなければ $M^{o} \supset M^{\prime}$ を満たす $M^{\prime}$ が見つかつたわけで， $M^{\circ}$ は非極小と分かり亩却される.ここで, $M^{o} \subseteq M^{\prime \prime}$ を満たすようなモデル $M^{\prime \prime}$ が $r \mathrm{cmp}$ によって生成される ことはないことに注意.なぜならば, $\overline{M^{\circ}}$ と $C_{M^{\circ}}$ の制約 があるからである．また, 前述のように, 相補分割のも とでは同一モデルが証明木上異なる 2 本の枝で生成され ることはないので, 同一モデルに対し $r \mathrm{cmp}$ が 2 度以上 呼ばれて極小と判定されることはない．

Niemelä の方法との若干の差異は, 上述の $C_{M^{\circ}}$ の代 りに短縮負節 $L_{k_{1}}^{o} \wedge \ldots \wedge L_{k_{r}}^{o} \rightarrow(r \leq m)$ を用いる点で ある.この短縮負節は $M^{o}$ 中の被委託選言要素 $L_{k_{i}}^{o}$ の みから構成される。たとえば，図 7 において，モデル $M_{3}=\left\{c^{1}, a^{2}, p^{2}\right\}$ が得られたとき, $c^{1} \wedge a^{2} \wedge p^{2} \rightarrow$ の代 りに短縮負節 $c^{1} \rightarrow$ が生成される．なぜならば， $c^{1}$ だけ が $M_{3}$ 中の被委託選言要素だからである .

短縮負節の使用は限定した極小性検査に相当しており， 被委託選言要素でないリテラルに対する根拠検査を省く ことができる. 兴の正当性は後に示す定理 4.4 によって 保証される.

\section{$3 \cdot 4$ 非極小モデルの早期刈り込み}

MM-SATCHMO では，極小モデルが得られる度にモ デル制約を付加するので，二れを包含するような非極小 モデルは構成の途中で事前に刈り取られる．しかし, 前 述の MM-MGTP 証明手続きや Niemeläの方法では, 確 定したモデルに対して極小性検査を行なうので，このよ うな非極小モデルの刚り込みは事後の処理となる . この

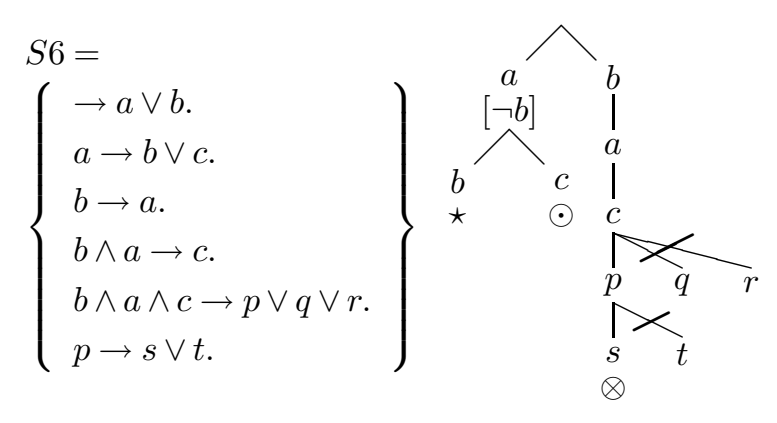

図 11 非極小モデルの早期刚り込み

欠点を補うため, モデル候補 $M$ が極小性検査により棄 却されるとき， $M$ より右の部分証明木の刚り込みを試行 する .

例えば，図 11 の節集合 $S 6$ を考える．モデル $M_{s}=$ $\{b, a, c, p, s\}$ が得られた時点で極小性検査が必要となる が, 弚の結果，極小モデル $M_{c}=\{a, c\}$ により包摂され ることが判明して棄却される.この後，モデル $M_{t}=\{b, a, c, p, t\}, M_{q}=\{b, a, c, q\}, M_{r}=\{b, a, c, r\}$ を 生成しても，いずれも極小性検査によって同じ理由で充 却されることが分かる.なぜならば, $M_{s}, M_{t}, M_{q}, M_{r}$ の 共通部分 $\{b, a, c\}$ がすでに $M_{c}$ により包捸されることが 分かるからである .

この枝刈りは，图 10 の xiii 行目の return $\emptyset を$ \{ prune $(M) ;$ return $\emptyset\}$ で置き換えるとともに，15 行目と vi 行目の間に

15.5: $\quad$ if $\left(\operatorname{pruned}\left(L_{j-1}\right)\right) \operatorname{return} \mathcal{M}$;
を挿入することにより，容易かつ効率良く実現できる． 手続き prune は, 証明木上の $M$ に対応する枝を葉から 根に向けて辿り， $M$ を包摂した $M^{\prime}$ の要素の一つ(図 11 では $c$ ) か現われるまで, 選言要素にあたる節点 (図 11 では $s$ と $p)$ に枝刈りの印を付けていく.一方, 関数 pruned は, 選言要素 $L_{j-1}$ に枝刘りの印か付されていれ ば真，さもなければ偽を返す．

この枝刈りは, 因子化 (証明委託) とは独立に極小モデ ル生成の観点から妥当となるものである . MM-MGTP においては，モデル記憶型，モデル再計算型に関わらず， この機構は標準的に実装される。

\section{4. 健全性と完全性}

本章では MM-MGTP 証明手続きの健全性と完全性に 関する結果を述べる. まず, 因子化に基づくモデル生成 が極小モデル生成に関して完全であることを示す .これ により，MM-MGTP 証明手続きも完全であることが示 される．なぜならば，分岐仮定と分岐補題の使用は因子 化の適用の一種とみなせるからである．次に，生成され たモデルが非極小であるための必要条件を与える . 限定 した極小性検査は，この必要条件を満たしている場合に 
必ず行われるので, この検査を行うモデル生成は極小モ デル生成に関して健全である．最後に，根拠検査に短縮 負節を用いても，生成されるモデルの極小性が保証され ることを示す．

[ 定理 4·1] $T$ を節集合 $S$ の証明木， $N_{1}$ および $N_{2}$ を $T$ 中の兄弟節点, $L_{i}$ を $N_{i}$ のラベル,$T_{i}$ を $N_{i}$ を根とす る $T$ の部分木とする $(i=1,2)$ (図 12(a)) .このとき， $N_{2}$ が $L_{1}$ のラベルをもつ節点 $N_{3}$ を子孫としてもつなら ば， $N_{3}$ を根とする $\left(T\right.$ の) 部分木 $T_{3}$ (図 12(b)) を通る 各モデル $M$ に対し， $M^{\prime} \subseteq M$ を満たすような， $T_{1}$ を通 るモデル $M^{\prime}$ が存在する .

《証明》 $T_{1}$ 中の節点の列 $N^{1}, N^{2}, \ldots$ を以下のように 帰納的に定義する。なお定義中， $I^{i}$ は $T$ の根から $N^{i} に$ 至る枝上に現れるリテラルの集合を表す．

先ず， $N^{1}=N_{1}$ と定義する .このとき $L_{1} \in I^{1}$ であ り，定理の仮定より $L_{1} \in M$ となるので, $I^{1} \subseteq M$ が成 り立つ。

さて次に,$\forall i(1 \leq i \leq n) .\left(I^{i} \subseteq M\right)$ を満たす節点の列 $N^{1}, N^{2}, \ldots, N^{n}$ が既に定義されているものと仮定する . このとき，節点 $N^{n+1}$ を次のように定義する .なお,$N^{n}$ に (失敗枝を示す) $\times$ の印が付けられていることはない． 光うであるとすると $M$ がモデルであることに反するか らである。

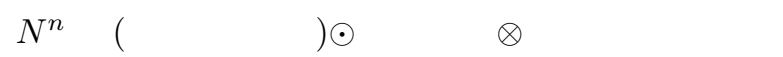
いる場合， $N^{n}$ を列の終端とする．

弚うでなければ $\left(N^{n}\right.$ の下に証明が続いていれば $), N^{n}$ で行われたモデル拡張に用いられた節を $\Gamma_{n} \rightarrow L_{1}^{n} \vee \ldots \vee$ $L_{m_{n}}^{n}$ とする .このとき, $I^{n} \models \Gamma_{n}$ かつ $I^{n} \not \models L_{1}^{n} \vee \ldots \vee$ $L_{m_{n}}^{n}$ が成り立つ．帰納法の仮定より $I^{n} \subseteq M$ がいえる ので， $M$ がモデルであることより,$M \models \Gamma_{n}$ かつ $M \models$ $L_{1}^{n} \vee \ldots \vee L_{m_{n}}^{n}$ が成り立つ.したがつて, $\exists i\left(1 \leq i \leq m_{n}\right)$ $L_{i}^{n} \in M$ が成り立つ.ここで, $k_{n}$ を $L_{k_{n}}^{n} \in M$ を満たす添 字とする.光して, $N^{n+1}$ を $N^{n}$ の子節点の内 $L_{k_{n}}^{n}$ でラ心゙ ル付けされているものと定義する .このとき,$L_{k_{n}}^{n} \in I^{n+1}$ であるので, $I^{n+1} \subseteq M$ が成り立つ .

以上のように定義した節点列は，ある節点 $N^{n}$ で有 限のうちに終わるか，無限に続くかのいずれかである . 前者の場合， $M^{\prime}$ は $I^{n}$ で与えられ，後者の場合， $M^{\prime}$ は $\lim _{i \rightarrow \infty} I^{i}$ で与えられる.いずれにしても， $\forall i(1 \leq$ i). $\left(I^{i} \subseteq M\right)$ であり， $M^{\prime} \subseteq M$ が成り立つ.

この定理により，証明 $T_{3}$ は極小モデル生成に関して 冗長であることが分かる.この冗長性を削除する因子化 を，因子化タブロー法 [Letz 94] と同樣の手法で定義す る.循環論法を避けるため, 証明木に対して因子化依存 関係を定義する．

【定義 4·1】証明木における因子化依存関係とは, 証 明木中の兄弟節点間の狭義の半順序々である.

兄弟節点 $N_{1}$ と $N_{2}$ の間に因子化依存関係 $N_{1} \prec N_{2}$ が あるとは, $N_{2}$ 以下の極小モデル探索が $N_{1}$ 以下の探索に 委託されることを意味している .
【定義 4·2】証明木 $T$ ならびに $T$ 上の因子化依存関係

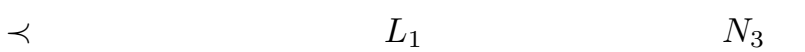
同じ $L_{1}$ のラベルをもつ節点 $N_{1}$ で, 以下の関係にある ものを選ぶ . (1) $N_{3}$ は $N_{1}$ の兄弟節点 $N_{2}$ の子孫である . (2) $N_{2} \nprec N_{1}$ である.次に， $N_{3}$ の枝を閉じ（^で印をつ

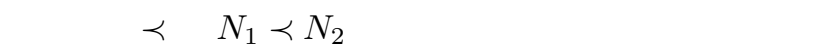

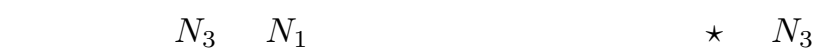
の証明が $N_{1}$ の証明に委託されたことを示す .この状況 を图 $12(\mathrm{~d})$ に図示する .

【定義 4·3】 通常の MGTP 証明手続き (図 1) に因子 化によるモデル棄却を加えたものを因子化に基づくモデ ル生成と呼ぶ．

定理 $4 \cdot 1$ より，次の系が直ちに導かれる．

（ 系 4·1） $S$ を節集合とする.$S$ の極小モデル $M$ がモ デル生成によって生成されるならば， $M$ は因子化に基づ くモデル生成によっても生成される．

モデル生成法は，值域限定された節集合に対する極小 モデル生成に関して完全 [Bry 96] (全ての極小モデルを 生成) なので, 系 $4 \cdot 1$ より，因子化に基づくモデル生成 も極小モデル生成に関して完全であることが分かる．

分岐仮定と分岐補題に基づくモデル生成は，乥れ艺れ $L_{1}, \ldots, L_{m}$ のラベルをもつ兄弟節点 $N_{1}, \ldots, N_{m}$ 間に因 子化依存関係を次のように設定することとみなせる．もし $L_{i}$ か涹託選言要素であるならば, すべての $j(i<j \leq m)$ について $N_{j} \prec N_{i}$ とする.逆に，ある $N_{j}(i<j \leq m)$ 以

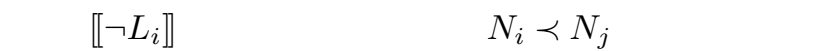
見方により，MM-MGTP 証明手続きの極小モデル生成 に関する完全性を述べた次の系が導かれる。

（系 4.2） $S$ を值域限定された充足可能な節集合， $T$ を分岐仮定と分岐補題に基づくモデル生成による $S$ の証 明木とする.$M$ が $S$ の極小モデルならば， $M$ は $T$ 中に 得られる.

因子化に基づくモデル生成は非極小モデルの生成を抑 制できるが，全く生成しないわけではない、証明手続き を健全にする，すなわち，極小モデルのみを生成させる ためには, 得られたモデルに対する極小性検査が不可欠 となる . 次の定理は得られたモデルが非極小であるため の必要条件を与える

[ 定理 4·2］ $S$ を節集合， $T$ を因子化に基づくモデル生 成による $S$ の証明木, $N_{1}$ と $N_{2}$ を $T$ 中の兄弟節点， $T_{i}$ を $N_{i}$ 以下の部分証明木, $M_{i}$ を $T_{i}$ を通るモデル $(i=1,2)$ とする .この時, $N_{2} \nprec N_{1}$ ならば， $M_{1} \nsubseteq M_{2}$ である .

《証明》 $N_{i}$ のラベルを $L_{i}(i=1,2)$ とする (図 $\left.12(\mathrm{a})\right)$. $N_{2} \nprec N_{1}$ から以下か導かれる . (1) $N_{1} \prec N_{2}$ ，あるいは (2) $N_{1}$ と $N_{2}$ の間に々関係がない .もし (1) が成立する ならば, $L_{1} \notin M_{2}$ である .なぜならば, $T_{2}$ 中の $L_{1}$ のラ ベルをもつ節点はすべて $N_{1}$ によって因子化されている はずだからである.一方， $L_{1} \in M_{1}$ である.したがって， $M_{1} \nsubseteq M_{2}$ である。もし (2) が成立するならば， $L_{1} \notin M_{2}$ である．なぜならば，因子化されなかったということは， 


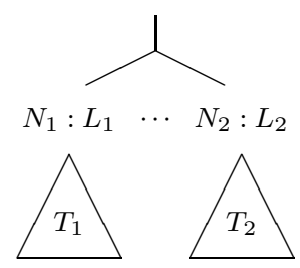

(a)

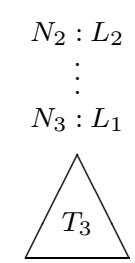

(b)

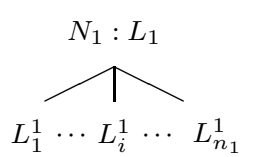

(c)

図 12 定理 $4 \cdot 1,4 \cdot 2$ と定義 $4 \cdot 2$ の説明図

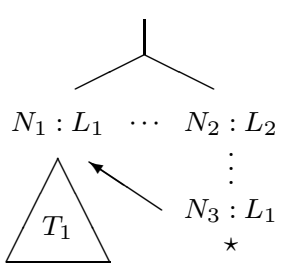

(d)
$T_{2}$ 中に $L_{1}$ のラベルをもつ節点は存在しないからである . したがって， $M_{1} \nsubseteq M_{2}$ である

定理 $4 \cdot 2$ によれば，(1) $N_{2} \nprec N_{1}$ ならば， $M_{2}$ の $M_{1}$ に対する極小性検査は不要であり，(2) $N_{2} \prec N_{1}$ ならば， $M_{2}$ の $M_{1}$ に対する極小性検査が必要である .

深さ優先・左優先探索による MM-MGTP において， 安全なモデルに対して極小性検査を省くことは, 上の (1) で正当化される . 要注意モデルに対して限定された極小 性検査を行なうことは，(2) で正当化される．もし $N_{1}$ が $N_{2}$ の左にある兄節点で， $N_{1} \prec N_{2}$ ，すなわち，分岐補

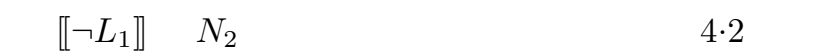
り， $M_{1}$ の $M_{2}$ に対する極小性検査が必要となる . しか し，MM-MGTP では，この検査は実は不要である.な ぜならば，常に $M_{2} \nsubseteq M_{1}$ が以下のようにして成立する からである .

[ 定理 4.3］ $T$ を因子化に基づくモデル生成の深さ優 先・左優先探索版による証明木とし,$M_{1}$ を $T$ 中のモデ ルとする. モデル $M_{2}$ が $T$ 中で $M_{1}$ の右に現われるなら ば， $M_{2} \nsubseteq M_{1}$ である

《証明》 $P_{M_{i}}$ を $M_{i}(i=1,2)$ に対応する経路とすると，

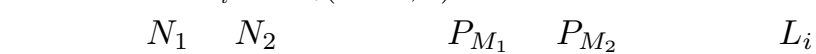
を $N_{i}(i=1,2)$ のラベルとする .ここで, $M_{2} \subseteq M_{1}$ と仮 定しよう．これは $L_{2} \in M_{1}$ を含意する．すると， $L_{2}$ のラ ベルをもつ節点 $N_{L_{2}}$ が $P_{M_{1}}$ 上に存在する . しかし, 深 さ優先·左優先探索では， $N_{L_{2}}$ は $N_{2}$ に因子化されるはず である.これは， $M_{1}$ が $T$ 中のモデルであるという定理 の仮定と矛盾する．したがって， $M_{2} \nsubseteq M_{1}$ である。

定理 $4 \cdot 2,4 \cdot 3$ より，MM-MGTP の極小モデル生成に 関する健全性が示される．次に，根拠検査のための短縮 負節が , 得られたモデルの極小性を保証することを意味 する定理を示す．

【定義 4.4】 $S$ を節集合， $T$ を因子化に基づくモデル生 成による $S$ の証明木， $M$ を $T$ 中に得られるモデルとする 各リテラル $L \in M$ に対し， $N_{L}$ は $M$ の経路中の $L$ のラ ベルをもつ節点を表す. $M_{p} \subseteq M$ を次の条件を満たす集 合とする.すべての $L \in M_{p}$ に対し， $N_{L} \prec N$ の関係に ある $N$ か存在する.すなわち,$M_{p}$ は $M$ 中の被委託選言 要素の集合であることに注意 . 短縮負節 $L_{1} \wedge \ldots \wedge L_{m} \rightarrow$ を $C_{M_{p}}$ で表す .ここで, $L_{i} \in M_{p}(i=1, \ldots, m)$ である.

[ 定理 4·4] $S$ を節集合とする.$M$ が $S$ の極小モデル
であるのは, $S_{M_{p}}=S \cup \bar{M} \cup\left\{C_{M_{p}}{ }^{* 6}\right\}$ が充足不能のとき であり，かつ光のときに限る.ここで， $\bar{M}=\left\{\neg L^{\prime} \mid L^{\prime} \notin\right.$ $M\}$ である.

《証明》 (Only-if part) $M^{\prime}$ を $S$ のモデルとする.$M$ と $M^{\prime}$ の関係により次の 3 つの場合に分けられる . (1) $M^{\prime} \backslash M \neq \emptyset$, (2) $M^{\prime}=M$, (3) $M^{\prime} \subset M$. (1) の場合 , $M^{\prime}$ は $\bar{M}$ 中の相補リテラルにより棄却される . (2) の場 合， $M^{\prime}$ は短縮負節 $C_{M_{p}}$ により棄却される. (3) は $M$ が 極小であることと矛盾する．つまり，S のモデルで $S_{M_{p}}$ のモデルとなるものはない . したがって， $S_{M_{p}}$ は充足不 能である .

(If part） $T$ を因子化に基づくモデル生成による $S$ の証 明木とし， $M$ は非極小と仮定する.すると， $M^{\prime} \subseteq M$ で あるような $S$ のモデル $M^{\prime}$ が $T$ 中に得られる $. P_{M}, P_{M}^{\prime}$ を光れ光れ $M, M^{\prime}$ に対応する経路とすると，兄弟節点 $N, N^{\prime}$ が $T$ 中に存在し,$N$ が $P_{M}$ 上に,$N^{\prime}$ が $P_{M}^{\prime}$ 上に ある. $L, L^{\prime}$ を光れ光れ $N, N^{\prime}$ のラベルとする.$N \prec N^{\prime}$ の場合， $M^{\prime}$ は $L \notin M^{\prime}$ なので $L$ 前件に含む $C_{M_{p}}$ と矛 盾せず， $M^{\prime} \subseteq M$ なので $\bar{M}$ とも矛盾しない．したがっ て,$M^{\prime}$ は $S_{M_{p}}$ のモデルである .これは $S_{M_{p}}$ が充足不 能であることと矛盾する.$N \nprec N^{\prime}$ の場合， $L^{\prime}$ のラベル をもつ節点は $P_{M}$ 上に現われるはずはなく,$L^{\prime} \notin M$ か つ $L^{\prime} \in M^{\prime}$ が成立する.これは， $M^{\prime} \subseteq M$ と矛盾する. したがって， $M$ は極小である

\section{5. 性 能 評 価}

\section{$5 \cdot 1 \quad$ MM-MGTP の実装}

MM-MGTP の実装に当たっては，Java によって記述 された MGTP[藤田 98, 長谷川 99, 長谷川 00] を拡張し た. 本実装においては, 分岐仮定や分岐補題に関する操 作に対して Acell 機構 [長谷川 99, 長谷川 00] が中心的な 役割を果している.一般に，一つの集合に対して一つの Acell が定義され，任意の要素が光の集合に所属するか否 かを, 弚の要素が Acellへの参照をもつか否かで判別す る.ここでは，モデル候補に対して Acell 機構が適用さ れる. Acell 自体は一つの boolean 值を保持するメモリ セルで , 現モデル候補に対応する (しない) Acell は光の 値が真 (偽) となっている.真値 (偽値) をもつ Acell を active(inactive)であるといい, active(inactive)な Acell 
を参照している属性は active(inactive) であるといわれ る、根節点及び非ホーン拡張された各分枝に対して，光

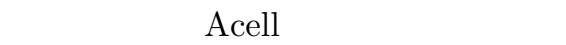

さて，まず，同一のリテラルが入力節集合やモデル候 補中に複数の出現をもつ場合に, インデキシング機構に よってすべて唯一の実体として参照できるようにしてお く.さらに，リテラルに対する樣々な問い合わせ，すな わち, 現モデル候補 $M$ の要素であるか否か $(a c)$, 分岐 仮定／補題として設定されているか否か $(\mathrm{asm} / \mathrm{lem})$ な どに応えるための属性スロットを各リテラル毎に用意す る. 弚れら各属性の直接の值は Acellへの参照とし, 意 味上の值は光の Acell の保持する boolean 值と等しいも のとする .

たとえば，選言 $d=L_{1} \vee \ldots \vee L_{n}$ で証明木の枝を非 ホーン拡張する際，予め各 $L_{i}(1 \leq i \leq n)$ の asm に, 親 の分枝に割り当てられた par-Acell ( $d$ の証明か終了する まで activeである) への参照を置く .これにより,$d$ 以 下の証明で有効な分岐仮定 $\left[\neg L_{1}\right] \wedge \ldots \wedge\left[\neg L_{n}\right]$ か設定さ れる. 個々の $L_{i}$ による拡張は左から順に行われ，兴の都 度, 対応する $L_{i}$ のasmの Acell 参照を inactive とし， 分岐仮定を無効化する.

また， $L_{i}$ の証明で，分岐仮定を用いて枝か閉じた場合， すなわち，ある弟選言要素 $L_{j}(i+1 \leq j \leq n)$ の ac, asm がともに activeなAcell を参照した場合， $L_{j}$ のasmに used-Acell (常に active な Acell) への参照を上書する . $L_{i}$ の証明が終了した時点で，ある弟選言要素 $L_{j}$ の asm が used-Acell を参照していれば， $L_{i}$ は委託選言要素で ある.さもなければ, $L_{i}$ の lem に par-Acell への参照を 置く ここれにより, 弟選言要素 $L_{i+1}, \ldots, L_{n}$ の証明に有 効な分岐補題 $\llbracket \neg L_{i} \rrbracket$ か設定される .この分岐補題によっ て枝が閉じられるのは，同樣に， $L_{i}$ の ac,lem がともに active なAcell を指すときである .

また，モデル記憶型 MM-MGTP における関数 $m c h k$ が， $M$ を包捸する極小モデルを求めて探索対象の部分木 の各枝を辿る間，光の枝上の各節点について，乥れをラ ベル付けしているリテラル $L$ か現モデル $M$ に含まれて いるかどうかを, $L$ の $a c$ 属性を見ることによって検査す る . $L$ が active ならば, $L \in M$ を意味しており,さも なければ $L \notin M$ である . 後者の場合 , $m c h k$ はただちに 兴の枝の探索を止め, 別の枝の探索に向かう. $m c h k$ が active な葉に至ったとき, 光の枝の表す極小モデルに $M$ が包捸されたことを意味し， $M$ が極小でないことが判明 する .

\section{$5 \cdot 2$ 実 験 結 果}

本節では, MM-MGTP と MM-SATCHMO および MGTP との比較実験結果について述べる . MM-MGTP については，4つの版を比較する．すなわち，モデル再 計算型の分岐補題有りと無し (Rcmp+BL / Rcmp) , お よびモデル記憶型の分岐補題有りと無し (Mchk+BL /
Mchk) である . MM-MGTPTP と MGTP は Java で， MM-SATCHMO[Bry 99] は ECL ${ }^{i}$ PS $^{e}$ Prolog で実装さ れている . すべての実験は Sun Ultra10 (333 MHz,128 $\mathrm{MB})$ 上で行なった .

結果を表 1 に示す. 実験には以下の例題を用いた . ex1

$$
\begin{gathered}
S_{n}=\left\{\rightarrow a_{k} \vee b_{k} \vee c_{k} \vee d_{k} \vee e_{k} \vee f_{k} \vee g_{k} \vee\right. \\
\left.h_{k} \vee i_{k} \vee j_{k} \mid k=1, \ldots, n\right\}
\end{gathered}
$$

これは MM-SATCHMO のベンチマーク例題から の引用である . ex1 の MG 木は各分岐が分岐数 10 の平衡木であり，生成されるモデルは全て極小であ る.すべての成功枝か被委託選言要素を含まないの で, 対応するモデルは安全であり, 極小性検査は不 要である。

ex2

$$
\begin{gathered}
S_{n}=\left\{a_{i-1} \rightarrow a_{i} \vee b_{i} \vee c_{i}, b_{i} \rightarrow a_{i}, c_{i} \rightarrow b_{i} \mid\right. \\
i=2, \ldots, n\} \cup\left\{\rightarrow a_{1}\right\}
\end{gathered}
$$

ex2 の MG 木は右に重い非平衡木である.最左枝 が唯一の極小モデルを与え, 光の右側のモデルはす ベてこれに包捸される. 分岐補題を用いれば，これ ら非極小モデルのすべてが棄却される . ex3

$$
\begin{aligned}
T_{1}= & \left\{\rightarrow a_{1} \vee b_{1}, a_{1} \rightarrow b_{1}, b_{1} \rightarrow a_{2} \vee b_{2},\right. \\
& \left.a_{2} \rightarrow b_{2} \vee d_{1}\right\} \\
T_{2}= & \left\{b_{2} \rightarrow a_{3} \vee b_{3}, a_{3} \rightarrow a_{2} \vee c_{2},\right. \\
& \left.a_{3} \wedge a_{2} \rightarrow b_{3} \vee d_{2}, a_{3} \wedge c_{2} \rightarrow b_{3} \vee d_{2}\right\} \\
T_{j}= & \left\{b_{j} \rightarrow a_{j+1} \vee b_{j+1}, a_{j+1} \rightarrow a_{j} \vee c_{j},\right. \\
& c_{j} \rightarrow a_{j-1} \vee c_{j-1}, a_{j+1} \wedge a_{2} \rightarrow b_{j+1} \vee d_{j}, \\
& \left.a_{j+1} \wedge c_{2} \rightarrow b_{j+1} \vee d_{j}\right\}(j \geq 3) \\
S_{n}= & \bigcup_{i=1}^{n} T_{i}
\end{aligned}
$$

ex3 の MG 木は ex2 と同樣に, 右に重い非平衡木

である.すべての成功枝が被委託選言要素を含んで おり，極小性検査が省けない，しかし，いずれのモ デルもこの検査によって棄却されない . ex4

ex5

$$
\begin{aligned}
S_{a}= & \left\{\rightarrow a_{i} \vee b_{i} \vee c_{i} \vee d_{i} \vee e_{i} \mid i=1, \ldots, 4\right\} \cup \\
& \left\{a_{3} \rightarrow a_{2}, a_{4} \rightarrow a_{3}, a_{1} \rightarrow a_{4}\right\}
\end{aligned}
$$

$$
\begin{aligned}
S_{a b c d}= & S_{a} \cup\left\{b_{3} \rightarrow b_{2}, b_{4} \rightarrow b_{3}, b_{1} \rightarrow b_{4}\right\} \cup \\
& \left\{c_{3} \rightarrow c_{2}, c_{4} \rightarrow c_{3}, c_{1} \rightarrow c_{4}\right\} \cup \\
& \left\{d_{3} \rightarrow d_{2}, d_{4} \rightarrow d_{3}, d_{1} \rightarrow d_{4}\right\}
\end{aligned}
$$

ex4 と ex5 は [Niemelä 96] の論文からの引用であ る.いずれも非極小モデルはすべて分岐補題によっ て棄却でき，極小検査が不要となる．

syn9-1

TPTP ライブラリ [Sutcliffe 94] から引用した一階 述語論理の例題で, 充足不能である.したがって, 極 小性検査は行なわれない .

channel

一階述語論理で記述したチャネルルーティング問題 
表 1 実行性能比較

\begin{tabular}{|c|c|c|c|c|c|c|}
\hline Problem & Rcmp+BL & Mchk+BL & Rcmp & Mchk & MM-SATCHMO & MGTP \\
\hline \multirow{3}{*}{$\begin{array}{c}\text { ex1 } \\
(\mathrm{N}=5)\end{array}$} & $\overline{0.271}$ & $\overline{0.520}$ & 2.315 & 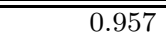 & $\overline{8869.950}$ & $\overline{0.199}$ \\
\hline & 100000 & 100000 & 100000 & 100000 & 100000 & 100000 \\
\hline & 0 & 0 & 0 & 0 & 0 & 0 \\
\hline \multirow{3}{*}{$\begin{array}{c}\mathrm{ex} 1 \\
(\mathrm{~N}=7)\end{array}$} & 34.150 & $\mathrm{OM}(>144)$ & 324.178 & $\mathrm{OM}(>115)$ & $\mathrm{OM}(>40523)$ & 19.817 \\
\hline & 10000000 & - & 10000000 & - & - & 10000000 \\
\hline & 0 & - & 0 & - & - & 0 \\
\hline \multirow{3}{*}{$\begin{array}{c}\mathrm{ex} 2 \\
(\mathrm{~N}=14)\end{array}$} & 0.001 & 0.001 & 82.112 & 16.403 & 1107.360 & 9.013 \\
\hline & 1 & 1 & 1 & 1 & 1 & 1594323 \\
\hline & 26 & 26 & 1594322 & 1594322 & 1594323 & 0 \\
\hline \multirow{3}{*}{$\begin{array}{c}\text { ex3 } \\
(\mathrm{N}=16)\end{array}$} & 19.816 & 5.076 & 19.550 & 5.106 & OM $(>2798)$ & 589.651 \\
\hline & 65536 & 65536 & 65536 & 65536 & - & 86093442 \\
\hline & 1 & 1 & 1 & 1 & - & 0 \\
\hline \multirow{3}{*}{$\begin{array}{c}\text { ex3 } \\
(\mathrm{N}=18)\end{array}$} & 98.200 & 26.483 & 95.436 & 26.103 & OM $(>1629)$ & 5596.270 \\
\hline & 262144 & 262144 & 262144 & 262144 & - & 774840978 \\
\hline & 1 & 1 & 1 & 1 & - & 0 \\
\hline \multirow[t]{3}{*}{ ex4 } & 0.002 & 0.002 & 0.009 & 0.003 & 0.3 & 0.004 \\
\hline & 341 & 341 & 341 & 341 & 341 & 501 \\
\hline & 96 & 96 & 160 & 160 & 284 & 0 \\
\hline \multirow[t]{3}{*}{ ex5 } & 0.001 & 0.001 & 0.002 & 0.001 & 0.25 & 0.001 \\
\hline & 17 & 17 & 17 & 17 & 17 & 129 \\
\hline & 84 & 84 & 88 & 88 & 608 & 0 \\
\hline \multirow[t]{3}{*}{ syn9-1 } & 0.105 & 0.109 & 0.101 & 0.092 & $\mathrm{TO}(>61200)$ & 0.088 \\
\hline & & 0 & 0 & 0 & - & 0 \\
\hline & 19683 & 19683 & 19683 & 19683 & - & 19683 \\
\hline \multirow[t]{3}{*}{ channel } & 4.016 & 4.064 & 46.166 & 4.517 & $\overline{\mathrm{NA}}$ & 3.702 \\
\hline & 51922 & 51922 & 51922 & 51922 & - & 51922 \\
\hline & 78 & 78 & 78 & 78 & - & 78 \\
\hline
\end{tabular}

top: time (sec), middle: No. of models, bottom: No. of failed branches.

OM: Out of memory, TO: Time out, NA: Not available due to lack of constraint handling

[Zhou 95] で, 負リテラルによる制約伝搬が探索空 間の刚り込みに本質的に働く例題である．極小性検 査を行なわない MGTP でも，すべて極小のモデル が得られる。

最後の二つの例題は, MM-MGTP の極小性検査のオー バヘッドを評価する目的に用いた .

\section{MM-MGTP 対 MM-SATCHMO}

MM-SATCHMO は, メモリオーバフローにより害行 不可能となる場合が多く，ここでは，MM-SATCHMO が解くことができた問題のみを考察の対象とする．極小 性検査が不要な $\mathrm{ex} 1$ や分岐補題力゙絶大な枝刈り効果を発 揮する ex2 において，MM-MGTP の顕著な優位性が認 められる . MM-MGTP の最速の版 (Rcmp+BL) では， ex1 と ex2 において, MM-SATCHMO に対する速度比 は 33,000 から $1,100,000$ 倍に達する . ex4や ex5 のよう な小さな問題でも，MM-MGTP は MM-SATCHMO よ り 100 倍以上速い .

ex1 における Mchk と MM-SATCHMO の比較は興味 深い.この場合, 分岐補題が適用されないので, 両者と も同数のモデルに対して極小検査が行なわれる. 実験結 果は, Acell 機構つき MM-MGTP の基本推論部が MMSATCHO の光れより数 10 倍速い*7としても, 光れから

\footnotetext{
*7［長谷川 00]によれば, MGTP では主要操作が基礎項の所属 検査に帰着され, 乥れが Acell 機構を用いて項数に依らない定 数時間量で実現された結果, 線形検索を含むSATCHMO の実
}

さらに 100 倍以上も高速化されていることを示している . これは, 証明木の踏査による極小性検査がモデル制約によ る乥れよりもはるかに効率的であることを証左している． ちなみに, Niemeläのシステム ${ }^{8}$ は ex4 と ex5 を光れ ぞれ 2 秒弱と 0.5 秒て解いている [Niemelä 96] .

\section{MM-MGTP 対 MGTP}

分岐補題および極小性検査によって棄却される非極小 モデルの数が増大するほど，MM-MGTP の証明時間は MGTP に比べ大きく短縮化される。特に, ex2 と ex3 は，極小モデル生成における分岐補題の効果か顕著であ る .ex1, syn9-1, channel は非極小モデルが作られない 問題であるが，分岐補題を用いる MM-MGTP は極小性 検査が省けるため, オーバヘッドは数 $10 \%$ 以内と比較的 小さい .

\section{Rcmp 対 Mchk}

項メモリ [Stickel 89] を用いずに済む ex1（N=7は除 外) から ex5の命題論理の問題に対して, Rcmp の証明時 間はMchk に比へ，再計算のオーバヘッドにより 2 から 5 倍に増加している .一方, 一階述語論理の問題 channel に対しては，Rcmp は Mchk の約 10 倍遅くなっている . これは, 項メモリへのアクセスオーバヘッドが大きいこ とに加え，根拠検査の実行によって項メモリへのアクセ ス頻度が倍化するためである．次に分岐補題の効果を見

装に対して数倍から数 10 倍速くなったと報告されている
$* 8$ Niemelä の処理系が入手できず, 正確な比較はできない . 
てみる . ex1 と channel においては, 分岐補題により極 小性検査が省かれるので, Rcmp+BL と Mchk は分岐補

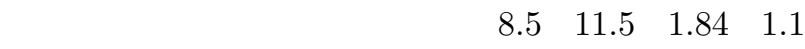
倍，高速である.Mchk+BL における高速化の度合が小 さいが，これは逆に，証明木の踏査に基づくMchk が極 めて効率良いことを示している . ex2 が分岐補題の効果を 示す典型的な問題であり，Rcmp+BL と Mchk+BL の 双方とも数万倍の高速化を達成している.

\section{Rcmp+BL 対 Mchk+BL}

極小性検査を省けない ex 3 の場合, Mchk+BL は $\mathrm{Rcmp}+\mathrm{BL}$ より 4 倍ほど速い .一方， $\operatorname{ex1}(\mathrm{N}=5)$ では， $\mathrm{Mchk}+\mathrm{BL}$ と Rcmp+BL との差異は原理的にないはずで あるが, 前者が後者より約 2 倍塀い 、これは, Mchk+BL がすべてのモデルを記憶せねばならず，ゴミ集めを頻繁 に引き起こしているためである .

\section{6. 関 連 研 究}

タブローの枠組において , Letz はタブロー木の枝刈り を行なう因子化 [Letz 94] を提案した . しかし, 因子化 は反駁証明への適用を目的にしており，[Letz 94] では極 小モデル生成については何ら言及されていない，相補分 割（あるいは [Letz 94] における folding-down）は因子 化の制限された実装の一つである .この制限は選言要素 間の優先関係が予め決定されている点にあり，優先順位 の高い選言要素のみが，关の証明を低い優先順位の他の 兄弟選言要素の証明に委ねることができる . 因子化にお いては，このような優先関係は事前に決定されない．因 子化は相補分割よりも枝刈り能力の点において強力では あるが，何らかの証明制御を行なわない限り，非極小モ デルを生成する可能性がある .

$\mathrm{Lu}[\mathrm{Lu}$ 96] は分岐仮定を対称的に付加することにより， 上の制限を緩和した極小モデル生成法を示した .これに よると, $a \vee b$ は $(a \wedge[\neg b]) \vee(b \wedge[\neg a])$ のように扱われ る.しかし, この方法では選言要素間の優先順位を事後 に定める必要がある．対称的な分岐仮定によって，証明 の相互委託が起こる可能性があるからである .このよう な場合，閉じてはならない枝が閉じられ，証明が健全で なくなる (モデル生成の観点から完全でもなくなる)．し たがって，弚のように一旦誤って閉じられた枝を事後に 再び開く必要があるが, このような操作は効率を著しく 低減させる。

本論文で提案した分岐補題もなお，因子化の制限され た実装法とみなせる．というのも，ある選言要素の証明 に光の弟の選言要素に起因する分岐仮定が用いられた場 合, 証明の相互委託か実際に生じるか否かにかかわらず， 分岐補題の生成が抑制されるからである，弚れでも，因 子化依存関係の推移閉包を計算する必要がないので, 我々 の方法は因子化を極小モデル生成に適用する効率的な方 法といえる . 分岐補題の効果は次のようにまとめられる .
（1）非極小モデルの生成を大きく抑制できる，(2) 不要な 極小性検査を省ける，(3) 現モデル候補 $M$ に対する極小 性検査の範囲を $M$ に関する委託選言要素か現われるモ デルに限定できる.

モデル記憶型の MM-MGTP は, 分岐補題の導入によっ て MM-SATCHMO を改良するのが狙いであり, 相補分 割と制約下探索に基づくものである . 両システムの主な 差異は以下のとおりである . MM-SATCHMO はモデル 制約を負節の形で記憶し，極小性検査をこの負節に対す る連言照合によって実行する．したがって時間量，記憶 量とも効率が悪くなっている．一方，我々のモデル記憶 型はより効率が良い，なぜならば，モデル制約は証明木 の形で記憶され，複数のモデルが共通部分を共有できる 構造になっていることと，分岐補題を用いることにより 極小性検査が抑制されているからである．

上述の両システムともメモ機構の一種であるモデル制約 に基づいているため, 記憶量の消費か著しく，最悪の場合 指数的に増大する .この状況は, Niemeläの方法 [Niemelä 96]によって回避しうる .この方法では, 以前に見つかっ た極小モデルに対する極小性検査をせずに，あらゆる非 極小モデルを棄却できる .これには，相補分割と等価な cut rule と制約下探索の代替とみなせる根拠検査が用い られている。

モデル再計算型の MM-MGTP は , この Niemelä の 方法の利点を備えており，モデル制約を記憶する必要が ない．しかし，両者とも制約下探索よりは高価な根拠検 査を繰り返し実行する．しかも，各極小モデルを 2 度生 成することになる．我々のモデル再計算型では，短縮負 節の導入によりこの問題は幾分軽減されている.さらに， 分岐補題により，根拠検査の回数をできる限り抑制する ことができる .

ほかに, 混合整数計画法に基づいた手法 [Bell 94, Bell 96] が報告されている. 対象は命題論理に限定されるが， すでに実用に供されている整数計画法ソフトウェアパッ ケージを利用して，節集合の変換等以外には特別な処理 を導入することなく極小モデルを効率的に求めることが できる.この方式の述語論理に向けた拡張や我々の方式 との比較評価は興味深いテーマと考えられるが，本稿の 範囲外であり，今後の課題である .

\section{7.む す び}

分岐仮定と分岐補題に基づく効率的な極小モデル生成 法について述べた .本研究は, 相補分割と制約下探索に基 づくBry の方法 , ならびに根拠検査を採用した Niemelä の方法に動機づけられている . 両方法とも几長な計算を 多く含んでおり，これらは本論文で提案した分岐補題と いう安価な機構によって抑制できる.実際，MM-MGTP の実験結果から，いくつかの問題において何桁もの速度 向上効果が得られることが示された . 


\section{ただし，我々の方法でも , 分岐補題が適用できない場合} には,依然として極小性検査が省けない，これに関しては， たとえば節集合に対する解析を行なうことにより，でき るだけ多く極小性検査を省けるように改良することが今 後の課題である。さらに，ここで述べた方法を，folding$u p[$ Letz 94] や制限なしの完全因子化のような刚り込み 技法と組み合わせたり，安定モデル生成に応用すること も有望と考える。

\section{$\diamond$ 参 考文 献 $\diamond$}

[Bell 94] Bell, C., Nerode, A., Ng, R. T., and Subrahmanian, V. S.: Mixed integer programming methods for computing nonmonotonic deductive databases, J. of the ACM, Vol. 41, No. 6, pp. 1178-1215 (1994).

[Bell 96] Bell, C., Nerode, A., Ng, R. T., and Subrahmanian, V. S.: Implementing deductive databases by mixed integer programming, ACM Trans. on Database Systems, Vol. 21, No. 2, pp. 238-269 (1996).

[Bry 96] Bry, F. and Yahya, A.: Minimal Model Generation with Positive Unit Hyper-Resolution Tableaux, in Proc. of 5th Workshop on Theorem Proving with Analytic Tableaux and Related Methods, LNAI 1071, pp. 143-159 (1996).

[Bry 99] Bry, F.: http://www.pms.informatik.unimuenchen.de/sof tware/MM-SATCHMO (1999).

[藤田 98] 藤田, 長谷川：Java 言語によるモデル生成型定理証明 系 MGTP の実装, 九州大学大学院システム情報科学研究科報 告, Vol. 3, No. 1, pp. 63-68 (1998).

[長谷川 99] 長谷川, 藤田 : 制約問題を解くためのモデル生成型 定理証明系の新実装, 九州大学大学院システム情報科学研究科 報告, Vol. 4, No. 1, pp. 57-62 (1999).

[長谷川 00] 長谷川, 藤田 : Java によるモデル生成型定理証明 系 MGTP の開発, 情報処理学会論文誌, Vol. 41, No. 6, pp. 1791-1798 (2000).

[Letz 94] Letz, M. K., R. and C., G.: Controlled Integration of the Cut Rule into Connection Tableau Calculi, J. of Autonated Reasoning, Vol. 13, pp. 297-337 (1994).

[Lu 96] Lu, W.: Minimal Model Generation Based on Ehyper Tableaux, Research reports 20/96, Inst. für Informatik, Univ. Koblenz (1996).

[Niemelä 96] Niemelä, I.: A Tableaux Calculus for Minimal Model Reasoning, in Proc. of 5th Workshop on Theorem Proving with Analytic Tableaux and Related Methods, LNAI 1071, pp. 278-294 (1996).

[白井 97] 白井, 長谷川 : モデル生成型定理証明システムによる制 約充足問題の解決と光の並列化, 電子情報通信学会論文誌, Vol. J80-D-II, No. 1, pp. 224-236 (1997).

[Stickel 89] Stickel, M.: The Path-Indexing Method For Indexing Terms, Technical Note 473, AI Center, SRI International (1989).

[Sutcliffe 94] Sutcliffe, G., Suttner, C., and Yemenis, T.: The TPTP Problem Library, in Proc. of the 12th Int. Conf. on Automated Deduction (CADE), LNAI 814, pp. 252-266, Springer-Verlag (1994).

[Zhou 95] Zhou, N.: A Logic Programming Approach to Channel Routing, in Proc. 12th Int. Conf. on Logic Programming, pp. 217-231, MIT Press (1995).

〔担当委員 : 新田克己〕

2000 年 5 月 11 日 受理

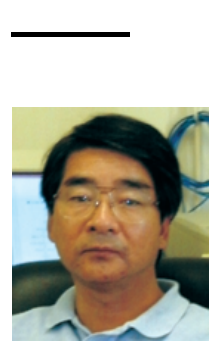

\section{者 紹}

長谷川 隆三(正会員)

1972 年九州大学大学院工学研究科通信工学専攻修士課程 修了. 同年 日本電信電話公社入社. 1987 1995 年 (財) 新世代コンピュータ技術開発機構出向 . 現在九州大学大学 院教授。博士 (工学) .論理プログラミング, 定理証明, 自 動推論システムなどに関する教育・研究に従事 . 情報処理 学会, 電子情報通信学会各会員

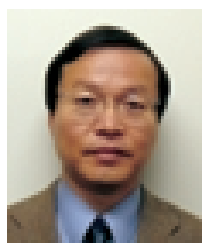

\section{藤田 博(正会員)}

1978 年 東京大学大学院工学系研究科情報工学専攻修士課 程修了. 同年三菱電機 (株) 入社. 1984 1990 年 (財) 新世代コンピュータ技術開発機構出向. 現在九州大学大学 院助教授 ·博士 (工学) .論理プログラミング, 自動推論シ ステムなどに関する教育・研究に従事 . 情報処理学会, 電 子情報通信学会, 日本ソフトウェア科学会, ACM 各会員.

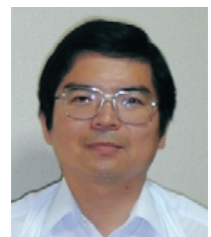

越村 三幸(正会員)

1984 年 筑波大学第一学群自然学類卒業. 1986 年 同大学 大学院修士課程理工学研究科修了.同年 日本ビジネスオー トメーション (株) (現在 東芝情報システム (株)) 入社 . 1986 1990,1993 1995 年 (財) 新世代コンピュータ 技術開発機構出向．1995 年 九州大学助手，現在に至る。 情報処理学会, 日本ソフトウェア科学会各会員。 